\title{
APLICATION OF THE STEREOLITHOGRAPHY TECHNIQUE IN COMPLEX SPINE SURGERY
}

\author{
Wellingson Silva Paiva', Robson Amorim?', \\ Douglas Alexandre França Bezerra', Marcos Masini'
}

\begin{abstract}
Many techniques have been proposed for surgical training as a learning process for young surgeons or for the simulation of complex procedures. Stereolithograpfy, a rapid prototyping technique, has been presented recently as an option for these purposes. We describe the case of a 12 years old boy, diagnosed with Ewing's sarcoma in the cervical spine. After a surgical simulation accomplished in the prototype, built by stereolithography, the patient was submitted to a C4 corpectomy and to a C4 and C3 laminectomy with anterior and posterior fixation, a non intercurrence procedure. This technique is an innovative and complementary tool in diagnosis and therapy. As a result, it is easier for the surgeon to understand the complexity of the case and plan the approach before any surgical procedure.
\end{abstract}

KEY WORDS: spine surgery, rapid prototyping, stereolithography.

\begin{abstract}
Aplicação da técnica de estereolitografia em cirurgias complexas da coluna
RESUMO - Lesões tumorais da coluna podem representar um grande desafio para equipe cirúrgica. A estereolitografia é uma técnica de construção de peças anatômicas a partir de desenhos gráficos ou exames radiológicos. Apresentamos um paciente de 12 anos, com quadro de cervicobraquialgia à direita com diagnóstico de sarcoma de Ewing. Ao exame neurológico, o paciente apresentava-se com paresia em MSD grau IV e leve hipoestesia em dermátomos de C6 à T1 à direita. RM evidenciou edema intra e extra-ósseo com compressão medular e instabilidade cervical. Realizada simulação cirúrgica no protótipo construído por estereolitografia. Foi submetido a corpectomia de C4 e a laminectomia C4 e C3, com fixação anterior e posterior, procedimento sem intercorrências. A estereolitografia é ferramenta inovadora no auxílio diagnóstico e terapêutico. Seu uso permite ao cirurgião entender fisicamente o sítio da lesão, estudar a via de acesso e perceber a real complexidade do caso antes do procedimento cirúrgico.
\end{abstract}

PALAVRAS-CHAVE: cirurgia da coluna, prototipagem rápida, estereolitografia.

Tumoral lesions of the spine can represent great challenges for a surgical team. Many techniques have been proposed for surgical training as a learning process for young surgeons or for the simulation of complex procedures. A rapid prototyping technique has been presented recently as an option for these purposes $^{1}$. Among prototyping forms the stereolithography, a technique developed in 1987 for aerospace industry stands out. It is based on models and graphic computation of images and create solid molds in resins, ceramic or metals ${ }^{1,2}$. As of the end of the 90's the first adaptations were accomplished for application in the biomedical area, substituting the drawings of graphic computation with images of a medical scanner such as computerized tomography (CT) and magnetic resonance image (MRI), whereby physical models of the human anatomy are built ${ }^{3}$. Several techniques of rapid proto- typing have been developed, and all are based on the construction of anatomical representations in a threedimensional structure, elaborated layer by layer ${ }^{1,4}$. The technology is based on the photopolimeryzing of a resin through an ultra violet laser. A controller positions a vertical elevator, initially on a container full of photosensitive resin, so that just a fine liquid layer is on the platform ${ }^{1,5}$. When the laser reaches the surface of the resin, this is solidified and the first layer of the model is built. After this, the elevator goes down submerging the layer recently solidified. The process of scanning laser is repeated and a second layer is elaborated on top of the first. The process of scanning laser is repeated so that the whole model is built. The purpose of this work is to demonstrate the practical use of the stereolithography an auxiliary method for training and surgical simulation'.

Clínica Queops de Neurologia e Neurocirurgia, Brasília DF, Brazil: ${ }^{1}$ Neurosurgery Resident of Hospital das Clinicas - University of São Paulo, São Paulo SP, Brazil; ²Professor of Neurosurgery, PhD - University of Planalto Central, Brasília DF, Brazil.

Received 27 June 2006, received in final form 1 December 2006. Accepted 10 February 2007. 

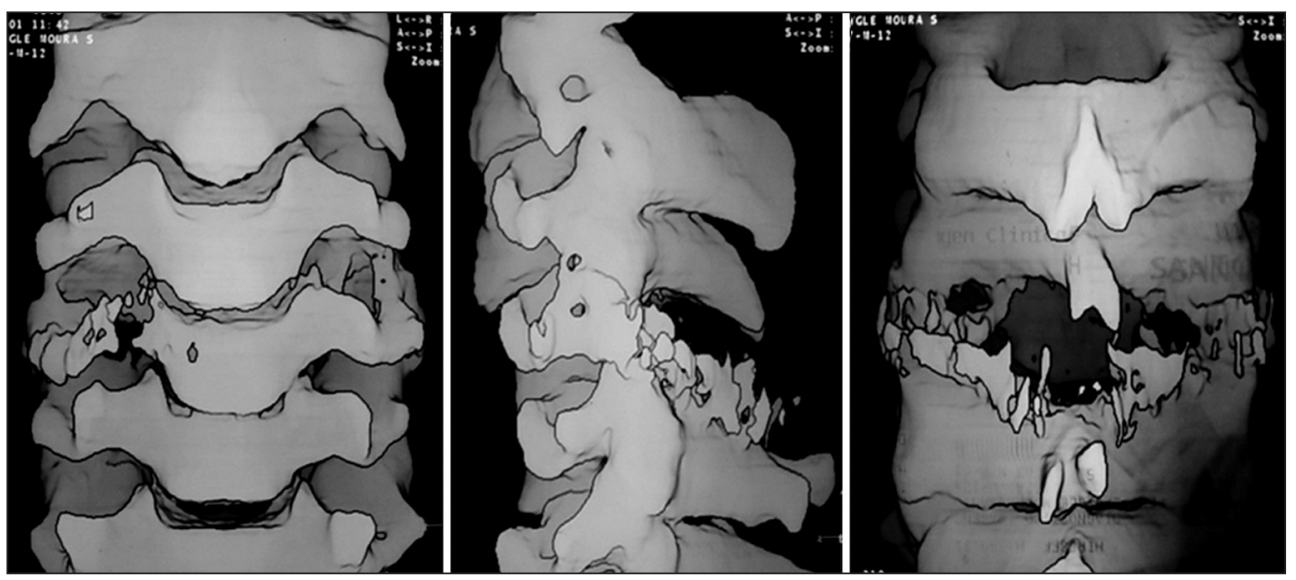

Fig 1. Computed tomography image with $3 D$ reconstruction of the case showing osteolytic lesion in cervical spine.

\section{METHOD}

This is a report of a case of the stereolithography technique application. In this case, the graphic models were used in extension ". stl". We used a specific device SLA 250 (3D system Inc. Valência, CA, USA) to elaborate the stereographic model. The radiologic images were transferred through an optical disk for better graphic interface. In this case a careful planning of the model with its surgery instrumental. This study was approved by the ethical committee

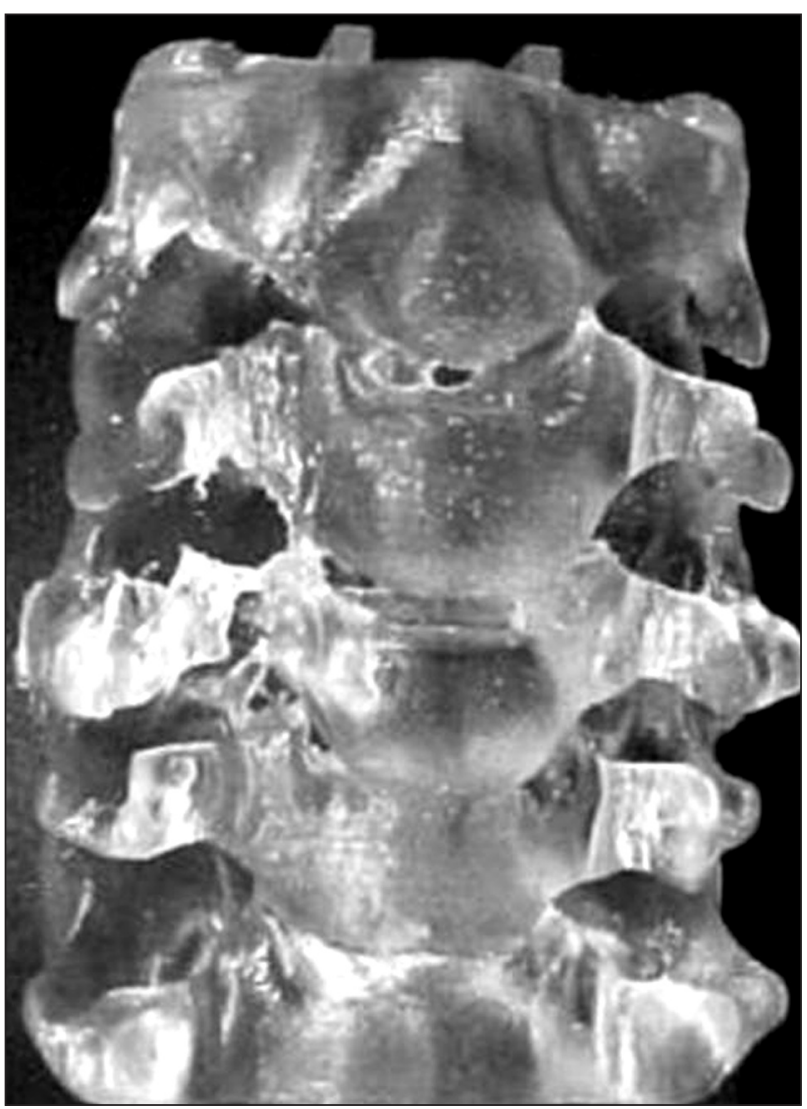

Fig 2. Anatomical representation of the patient's cervical spine, already in physical mold. of the institution and also its publication was authorized by child's guardians.

Case - We describe the case of 12 years old, white, male, student, complaining about a sudden and intense pain in the neck lasting for 45 days. According to the patient, 38 days after the symptoms had started the pain also reached the right arm. In the neurological examination the patient presented right arm paresis (grade 4) and slight hypoes-

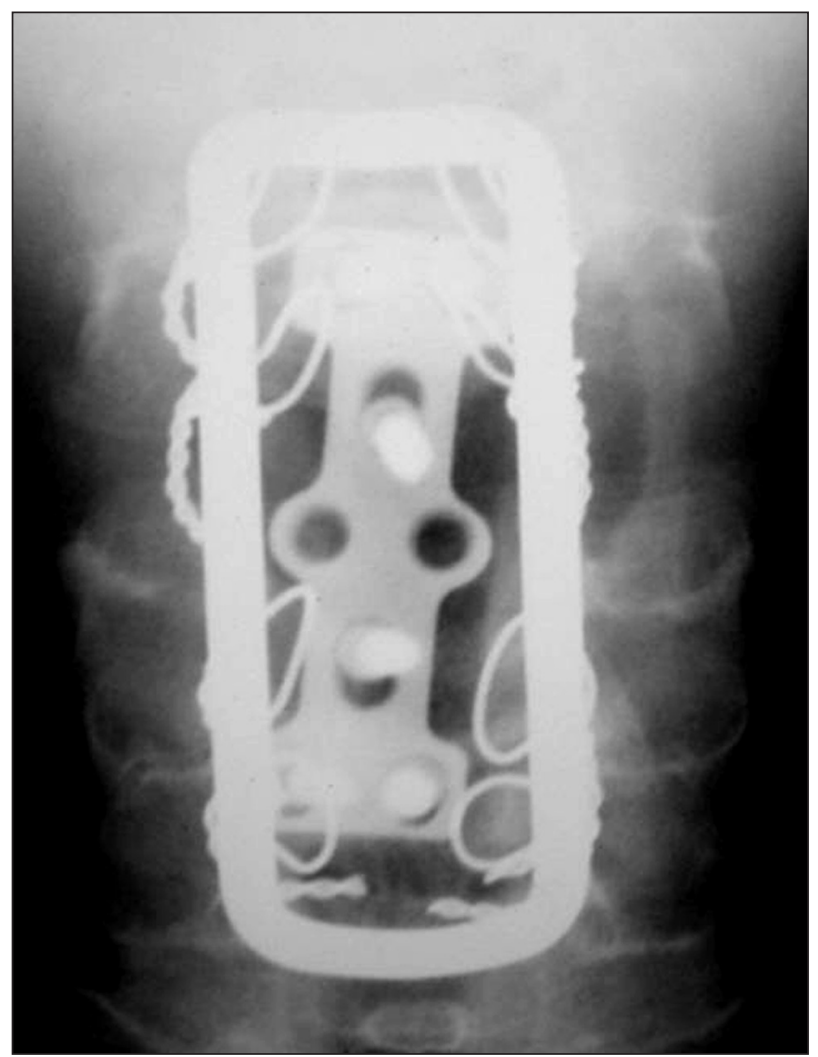

Fig 3. X-ray in AP of the cervical spine in the immediate postoperative time: cage/plate and screws anterior system and posterior cables in fixation system. 
tesia in C6 to T1 right dermathomus. In a complementary investigation (Figs 1 and 2) the X-ray of cervical spine indicated pathologic fracture of C4 vertebra with C4-C5 anterolistese (grade 1). The scyntilography of the whole body with Tc - 99 showed tenuous increase of osteogenic activity in C4. CT with tumoral lesion bone committing C4 with soft parts components (suggestive of osteoblastoma) MRI evidenced edema intra and extra-bone with spine compression and cervical instability.

After a surgical simulation accomplished in the prototype, built by stereolithography, the patient was submitted to a C4 corpectomy and to a C4 and C3 laminectomy with anterior and posterior fixation (Fig 3). The hystopathologic exam and immunohystochemic were compatible with neuroectodermic sarcoma of Ewing. The patient developed a partial redemption of painful symptoms and the recovery of his muscular force. Subsequently, the patient was submitted to a complementary radiotherapeutic treatment.

\section{DISCUSSION}

There were no complications during the procedure, which supports the idea that the process of stereolithography can be used in complex spine operations. In this case the previous training on stereolithographic mold allowed the procedure to be accomplished with an appropriated preparation besides evaluating the ideal dimensions of the plate system, screws and cables. This technique presents a great potential application, allowing visualization of tumors and its relationship with neighboring anatomy. It was described for visualization of maxillo-facial tumors and dental alterations ${ }^{3,5}$, stereotatics and brain aneurysm surgeries ${ }^{6}$, evaluation of dimensions of orthopaedics prostheses ${ }^{4}$. It is also possible to determine the standardization of surgical techniques, when accompanied by special procedures. In the case of surgery for placement of prostheses the stereo- lithographic model has been used to determine ideal dimensions of the material to be implanted".

Of all the techniques the stereolithography is the most used, presenting application in the aero-space industry for more than two decades ${ }^{1}$. The adaptation for medical appliance with the substitution of graphic drawings for radiological exams can be done without the loss of precision, maintaining a level with variation of $1 \mathrm{~mm}$ in the graphic interface ${ }^{7}$. The limitation for regular use of this technique is the high cost involved in prototyping process (the important support to complex procedures).

In conclusion, this technique is an innovative and complementary tool in diagnosis and therapy. As a result, it is easier for the surgeon to understand the complexity of the case and plan the approach before any surgical procedure. Careful planning and previous rehearsal reduce the risk of surprises during an operation. Moreover, it can improve decisional knowledge which represents an active role in a surgical procedure.

\section{REFERENCES}

1. Petzold R, Zeilhofer HF, Kalender WA. Rapid protyping technology in medicine basics and applications. Comput Med Imaging Graph 2002;23:277-284

2. Choi JY, Choi JH, Kim NK, et al. Analysis of errors in medical rapid prototyping models. Int J Oral Maxillofac Surg 2002;31:23-32.

3. D'Urso PS, Barker TM. Stereolithographic biomodelling in cranio-maxillofacial surgery: a prospective trial. J Craniomaxillofac Surg 1999;27:30-37.

4. Potamianos P, Amis AA, Forester AJ. Rapid prototyping for orthopaedic surgery. Proc Inst Mech Eng 1998;212:383-393.

5. Poukens J, Haex J, Riediger D. The use of rapid prototyping in the preoperative planning of distraction osteogenesis of the cranio-maxillofacial skeleton. Comput Aided Surg 2003;8:146-154

6. Wurm G, Tomancok B, Pogady P, Holl K, Trenkler J. Cerebrovascular stereolithographic biomodeling for aneurysm surgery: technical note. J Neurosurg 2004;100:139-145.

7. Webb PA. A review of rapid prototyping (RP) techniques in the medical and biomedical sector. J Med Eng Technol 2000;24:149-153. 